\title{
LIGHT AND SCANNING ELECTRON MICROSCOPY ON SERRASENTIS SAGITTIFER LINTON, 1889 (ACANTHOCEPHALA): \\ PALAEACANTHOCEPHALA: RHADINORHYNCHIDAE) INFECTING THE COMMON SEA BREAM IN EGYPT
}

By

HODA SAADY MOHAMADAIN and ASMAA ADEL

Department of Zoology, Faculty of Science, South Valley University, Qena, Egypt

\begin{abstract}
Serrasentis sagittifer is one of the most important acanthocephalan parasites parasitizing fish. This species attach to the intestinal wall via their armed proboscis which is anchored by rows of recurved spines. In the present study, Twenty two out of 50 fish specimens (44.0\%) were found to be naturally infected by adult worms of Serrasentis Sagittifer Linton, 1889 (Acanthocephala: Rhadinorhynchidae) which were collected from the stomach and intestine of the common sea bream Pagrus pagrus (family: Sparidae) from locations along the Red Sea at Hurghada City, Egypt. The light and scanning microscopic study revealed that the adult worm possessed a proboscis which was long, cylindrical with a uniform width measured $0.81 \pm 0.020$ $(0.77-0.84) \mathrm{mm}$ in length and $0.48 \pm 0.020(0.33-0.69) \mathrm{mm}$ in width. Claviform, armed with 25 (23-28) longitudinal rows of hooks which show a distinct dorsoventral asymmetry, with ventral hooks stouter, larger. Proboscis receptacle was $2.12 \pm 0.30$ (2.10-2.14) long, doublewalled, with ganglion at mid-level; two unequal, long and thin lemnisci 2.9 $\pm 0.30(2.41-3.33)$ length, arised from the base of the neck, and extend up to the med-level of the trunk. the present species is compared morphologically and morphometrically with some of the previously recorded species isolated from different host species, which revealed that the present species should be classified as Serrasentis sagittifer with a new host record in Egypt.

Key words: Serrasentis Sagittifer, Rhadinorhynchidae, Pagrus pagrus, light and scanning electron microscopy
\end{abstract}

\section{Introduction}

Members of phylum Acanthocephala are endoparasites without a digestive tract (Mehl-horn et al, 1988). The adult worms parasites live in the intestinal lumen of the host fish, attached to the wall of intestine, and the larvae (post-cystacanths) encapsulated in fish tissues (Tingbao and Xianghua, 2001). They have a complex life cycle with arthropods as inter-mediate hosts and vertebrates as definitive hosts causing various pathological conditions in many fin fish (Vignon and Sasal, 2010; Salgado-Maldonado, 2013). They are slender or slightly flattened worms infecting mainly fish, birds and mammals. Phylum diagnostic feature is the organ of attachment consisting of an invaginable proboscis that forms the anterior end (Herlyn et al, 2003). The probo-scis is armed with rows of recurved hooks, thus the common name of spiny-headed worms applied to these parasites (Hyman, 1951).
The trunk is a hollow structure that contains excretory, reproductive and nervous system and is filled with pseudocoelomic fluid (Martins et al, 2001; Santos et al, 2005). The other unique morphological features of acanthocephalans is a proboscis receptacle at the anterior end of the trunk and the paired lemnisci that extend into the trunk from neck. Taraschewski (2000) found that the pathogenicity of acanthocephalans is caused mainly by two factors; worms' density and depth of parasite penetration into the host tissues. He added that the pathological effects might be locali- zed around individual worms in low infection, but in the high parasite load, total destruction of the tissue architecture due to the occurrence of the collective pathological changes.

Acanthocephalans parasite the intestines of the wild fresh and salt water fishs. The irreversible mechanical damage caused by the armed pro-boscis attachment affects the 
intestinal tissues architecture leading to pathological changes. Loss/degeneration of intestinal villi, formation of the granular tissues and capsule formation associated with host immune responses that seriously affect animal's digestive and absorptive efficiency. In heavy infections they cause occlusion of the gut and invasion and migrate into uncommon locations (Nickol, 2006). The pathogenesis consequences of the parasitized fishes are well documented and serve as evidence that the parasites are one of the main causes of fish mortality. Diversity of acanthocephalans is limited to approximately 1150 described species. In Egypt, few studies were carried out on the acanthocephalan parasites infecting fish of the Red Sea and Arabian Gulf. Amin et al. (1984) described the two acanthocephalans Sclerocollum rubrimaris and Serrasentis sagittifer. The two different species Neoechinorhynchus qatanesis and $N$. dimorphospinus were described by Amin et al. (2002). Serrasentis sagittifer is one of the most important acanthocephalan parasitizing fish (Seyed et al, 2008). According to Integrated Taxonomic Information System (IT IS, 2011) a total of eight synonyms were adjusted; these were Serrasentis socialis Leidy (1851); Echinogaster sagittifer Linton (1889); Echi-norhynchus sagittifer Linton (1889); Serra-sentis longus Tripathi (1959); S. chauhani Datta (1954); S. giganticus Bilqees (1971); S. longiformis Bilqees (1971) and S. scomberomori Wang (1981).

The present study aimed to collect and describe the acanthocephalan parasite Serrasentis sagittifer of family Rhadinorhynchidae using morphological and morphometric analysis by the light and scanning electron microscopy

\section{Materials and Methods}

Fifty fish specimens of Pagrus pagrus (Family: Sparidae) were collected and examined for acanthocephalan parasites. The collection was done from January to October 2014 from boat landing sites along the coasts of the Red Sea and sometimes from the fish markets at Hurghada City, The Red Sea Governorate, Egypt.

The parasites were isolated from the intestine and pyloric ceca of the fish transferred to a clean saline solution by using a brush or small pipettes and washed several times by saline solution to remove any mucous or debris which is usually adhere to the body surface. Acanthocephalans were relaxed in tap water, this was important for their proboscis to be fully everted from their bodies (Gibson, 1985) then fixed in 10\% formalin. After fixation, the samples were washed in distilled water for 15 minutes to remove the excess fixative and then processed to staining which is carried out by using acetic acid alum carmine for 5-10 minutes (Carlton, 1967). After staining, a differentiation step must be carried out to remove the excess stain by placing the stained worms into the dilute solution of acid alcohol $(0.5 \mathrm{ml}$ in $100 \mathrm{ml}$ alcohol $)$, it is better to carry out this process under a binocular dissecting microscope to detect the end point of differentiation. This was followed by the dehydration in an ascending series of ethanol; 30\%, 50\%, 70\%, 90\%, 95\% and absolute ethanol, leaving the parasites for 2-5 minutes in each grade. The specimens were then cleared in xylene, then mounted in Canada balsam, covered with cover glass and left to dry in an oven at $40^{\circ} \mathrm{C}$. Prevalence, mean abundance and morphometric measurements followed the guidelines of Bush et al. (1997) of minimum and maximum values were given, followed in parentheses by the arithmetic mean $( \pm \mathrm{SD})$.

For scanning electron microscopy(SEM), the pleurocerci specimens were fixed in $4 \%$ buffered gluteraldehyde, washed in the cacodylate buffer and dehydrated in an ascending alcohol series. After passing through an ascending series of the Genosolv$\mathrm{D}$, they were processed in a critical point drier "Bomer-900" with freon 13 and sputter coated with goldpalla-dium in a Technics Hummer $\mathrm{V}$ and examined with an Etec Autoscan at $20 \mathrm{kV}$ Jeol SEM. 


\section{Results}

Twenty two (44\%) out of fifty specimens of fish were found to be naturally infected by an acanthocephalan parasite. The infection was in the intestine and stomach of fish but without visible signs or symptoms. Seasonally, the infection increased during summer $48.15 \%(13 / 27)$ and dropped to $39.13 \%$ (9/23) during winter.

Trunk was $7.8 \pm 0.50$ (7.6-7.9), with length and $0.64 \pm 0.020(0.60-0.67)$ width, elongate, sub-cylindrical, and somewhat enlarged anteriorly, with one or two fields of body spines separated by an aspinose region, with rows of distinctive spines (combs) on ventral surface of adult body and encysted stages. Hypodermis possessed numerous fragments of giant nuclei. The proboscis was very long $0.81 \pm 0.020 \quad(0.77-0.84) \quad$ in length and $0.48 \pm 0.020(0.33-0.69)$ in width, claviform, armed with 25(23-28) longitudinal rows of hooks each; hooks showing distinct dorsoventral asymmetry, with ventral hooks stouter, larger. Proboscis receptacle was $2.12 \pm 0.30$ (2.10-2.14) long, double-walled, with ganglion at mid-level; two unequal, long and thin lemnisci $2.9 \pm 0.30$ (2.41-3.33) length, arised from the neck base extending up to the trunk med-level, reached a level beyond testes. Male genitalia occupied posterior half of trunk. Testes were two ovoid to elongate, tandem, contiguous; cement glands 2-8, club-shaped; gonopore terminal in both sexes. Maleworm possessed a body which was elongated with a narrow posterior end. Two immature testes were ovoid, nearly equal and tandem, each $0.21 \pm 0.02(0.17-0.23)$ in diameter. Premordia of four cement glands were detected with pyriform shape, located at posterior end. Copulatory bursa is bell-shaped and muscular, with a ring like a sphincter.

In some female specimens, some immature ovarian balls seen near the receptacle. The vagina was surrounded by two pairs of the vaginal muscles.

Taxonomic summary:

Family: Rhadinorhynchidae (Travassos,
1923).

Host: Common sea bream Pagrus pagrus (Family: Sparidae, Linnaeus, 1758) and Red Mullet Mullus barbatus

Infection site: Intestine, pyloric ceca, body cavity, mesenteries and external surfaces of internal organs (as an encysted form).

Type locality: Red Sea Coasts at Hurghada City, Egypt.

\section{Discussion}

Genus Serrasentis was erected by Van Cleave (1923). Fifteen valid species of this genus were documented, which included Serrasentis sagittifer which is one of the most important pathogenic parasites of the digestive system of fish, especially intestine (Seyed et al, 2008). This species have a wide range of hosts, they were reported from a total 13 fish species from the Arabian Gulf, especially from the coasts of Iran, Kuwait and Emirates (Kardousha, 2005 ), from five fish hosts of Karachi coast (Bilqees and Khan, 1993), from 20 species of Atlantic ocean (Meyers, 1978), and from six species of Brazililian coasts (Luque and Poulin, 2004; Alves et al, 2005; Santos et al, 2005).

Morphologically, the present parasite resembled S. sagittifer previously recorded from Thunnus tonggol from Hodeidah coasts, Yemen by Al-Zubaidy and Mhaisen (2012) and from Saurida undosquamis from the Arabian Gulf by Kardousha (2005). The similarities between these species includ body dimensions, rows and shape of spines surrounding proboscis, the combs of trunk spines. In comparison to the other species belonging to genus Serrasentis, the present species differed from $S$. longus Tripatti (1959) in the number of trunk spines which were 12 in number followed by 3 small spines posteriorly compared to the present species which had 16-20 rows. Proboscis equipped by longitudinal rows of spines which are 6 each with 15-16 spines in $S$. longus compared to 9-11 rows each with 15-18 in the present species. Morpholo-gical assessment led to incongruent conclu-sion due to 
difficulties in their characters that distinguish taxa (Taraschewski, 2005). Many acanthocephalans species of family Rhadinorhynchidae were previously reported from the Red Sea and Persian Gulf. These were Sclerocollum rubrimaris (Amin et al, 1984), Siganus luridus from the coast of Sharm ElSheikh, South Sinai, Neoechinorhynchus qatanesis (Amin et al, 2002), Nemipterus japonicas from Bushehr coasts (tropical and subtropical-Indo west Pacific region), Neoechinorhynchus dimorphospinus (Amin et al, 2002), Dorodoma nasus in pisces from Kuwait and Serrasentis sagittifer (Amin et al, 1984) Thunnus tonggol, Sphyraena barracuda, Pomadasys argenteus, Lutjanus gibbus from coast of Yamen, Red Sea. The same species was reported from the spotted lizard fish Saurida undosquamis from the Arabian Gulf, Emirati Coasts (Kardousha, 2005) and from the gilthead Sea bream Sparus aurata (Abdel Ghaffar et al, 2014).

\section{Conclusion}

The morphological and morphometric com-parison between the present acanthocephalan parasite from the Pagrus pagrus and the previous ones morphologically are similar species from different hosts prove that it was Serrasentis sagittifier with new host record in Egypt.

\section{References}

Abdel-Ghaffar, F, Morsy, K, Abdel-Gaber, R, Mehlhorn, H, Al Quraishy, S, Mohammed, S, 2014: Prevalence, morphology, and molecular analysis of Serrasentis sagittifer (Acanthocephala: Palaeacanthocephala: Rhadinorhynchidae), a para-site of the gilthead sea bream Sparus aurata (Spa-ridae). Parasitol. Res. 113, 7:2445-54.

Alves, DR, Paraguassú, AR, Luque, JL, 2005: Community ecology of the metazoan parasites of the grey triggerfish, Balistes capriscus Gmelin, 1789 and queen triggerfish $B$. vetula Linnaeus, 1758 (Osteichthyes: Balistidae) from the State of Rio de Janeiro, Brazil. Rev Brasil. Parasitol. Vet. 14, 2:71-7.

Al-Zubaidy, AB, Mhaisen, FT, 2012: A record of two species of Acanthocephala (Echinorhynchida: Rhadinorhynchidae) from Red Sea fishes,
Yemeni coastal waters. Mesopot. J. Mar. Sci. 27, 1:15-28.

Amin, OM, Nahhas, FH, Al-Yamani, F, AbuHakima, R, 1984: On three acanthocephalan spe-cies from some Arabian Gulf fishes off the coast of Kuwait. J. Parasitol. 70:168-70.

Amin, OM, Saoud, MFA, Alkuwari, KSR, 2002: Neoechinorhynchus qatarensis sp. $\mathrm{n}$. (Acanthocephala: Neoechinorhynchidae) from bluebarred flame parrot fish, Scarus ghobban Forsskal, 1775, in Qatari waters of the Arabian Gulf. Parasitol. Int. 51, 2:171-6.

Bilqees, FM, Khan, A, 1993: Paraechinorhynchus kalriai n. g, n. sp. (Neoechinorhynchidea) from Labeo rohita (Ham). Pakistan J. Agric. Sci. 20, 3/4:116-20.

Bilqees, FM, Khan, A, 1993: Paraechinorhynchus kalriai $\mathrm{n}$. g, n. sp. (Neoechinorhynchidea: Neoechinorhynchinae) from Labeo rohita (Ham). Pakistan.J Agri. Sci. 20, 3/4: 116-20.

Bush. AO, Lafferty, KD, Lotz, JM, Shostak, W, 1997: Parasitology meets ecology on its own terms: Margolis et al. revisited. J. Parasitol. 83, 4:575-83.

Carleton, H, 1976: Carleton's histopathological technique 4th Ed. Oxford University Press, New York, Toronto.

Gibson, JW, 1985: Satisfaction with Upward and Downward Organizational Communications: Another Perspective. Proceedings of the Southwest Academy of Management (March): 150,

Herlyn, H, Piskurek, O, Schmitz, J, Ehlers, U, Zischlera, H, 2003: The syndermatan phylogeny and the evolution of acanthocephalan endoparasitism as inferred from 18S rDNA sequences. Mol. Phyl. Evol. 26:155-64.

Hyman, LH, 1951: The invertebrates-Acanthocephalan Aschelminthes and Entroprocta, McGraw Hill Publisher, USA.

Integrated Taxonomic Information System (ITIS), 2011: http://www.itis.gov

Kardousha, MM, 2005: Helminth parasite larvae collected from Arabian Gulf fish. IV- Description of four larvae including two metacercariae, one di-dymozoid and one acanthocephalan from Emirati coast. Arab Gulf J. Sci. Res. 23, 1:23-7.

Luque, JL, Poulin, R, 2004: Use of fish as inter-mediate hosts by helminth parasites: A compara-tive analysis. Acta Parasitologica. 49, 4: 353-61.

Martins, ML, Moraes, FR, Fujimoto, RY, Onaka, EM, Quintana, CIF, 2001: Prevalence 
and histopathology of Neoechinorhynchus curemai Noronha, 1973 (Acanthocephala: Neoechino-rhynchidae) in Prochilodus lineatus Valenciennes, 1836 from Volta Grande Reservoir MG Brazil. Brazilian. J. Biol. 61, 3: 517-22.

Mehlhorn, H, Taraschewski, H, Franz, M, Walldorf, V, Voigt, WP, 1988: Reproduction. In: Mehlhorn H (ed) Parasitology in Focus. Facts and trends. Springer, Berlin Heidelberg New York.

Meyers, TR, 1978: Prevalence of fish parasitism in Raritan Bay, New Jersey. Proceedings of the Helminthol. Soc. Wash. 45, 1:120-28.

Nickol, BB, 2006: Phylum Acanthocephala, In: Woo, P.T.K. (Ed.), Fish Diseases and Disorders, $2^{\text {nd }}$ Edition: Protozoan and Metazoan Infections, Vol. I. CAB International, Wallingford, UK.

Salgado-Maldonado, G, 2013: Redescription of Neoechinorhynchus (Neoechinorhynchus) golvani Salgado-Maldonado, 1978 (Acanthocephala: Neoechinorhynchidae) and description of a new spe-cies from freshwater cichlids (Teleostei: Cichlidae) in Mexico. Parasitol. Res. 112, 5: 1891-901.

Santos, RS, Martins, ML, Maregoni, NG, Francisco, CJ, Piazza, RS, et al, 2005: Neoechinorhynchus curemai (Acanthocephala: Neoechinrhynchidae) in Prochilodus lineatus (Osteichthyes: Prochilodontidae) from the Parana River, Brazil.Vet. Parasitol. 134:111-5.
Seyed, SGM, Majid, K, Mahnaz, K, 2008: Serrasentis sagittifer (Acanthocephala: Rhadinorhynchidae) from the Japanese thread fin bream, Nemipterus japonicus, in Bushehr water of Persian Gulf. J. An. Vet. Adv. 7, 11:1430-3.

Taraschewski, H, 2000: Host-parasite interactions in Acanthocephala: A morphological approach. Adv. Parasitol. 46: 1-179.

Taraschewski, H, 2005: Acanthocephala (thorny or spiny-headed worms). In: Rhode K, ed. Marine Parasitology, CSIRO Publishing, Collingwood.

Tingbao, Y, Xianghua, L, 2001: Seasonal population dynamics of Neoechinorhynchus quinghaiensis in the carp, Gymnocypris przewalskii przewalskii from Qinghai Lake, china. J Helminthol. 75:93-8.

Tripathi, YR, 1959: Studies on parasites of Indian fishes. V. Acanthocephala. Records of the Indian Museum. 54, 1/2:61-99.

Van Cleave, HJ, 1923: Telosentis, a new genus of Acanthocephala from southern Europe. J Parasit. 9:174-5.

Vignon, M, Sasal, P, 2010: The use of geometric morphometrics in understanding shape variability of sclerotized haptoral structures of monogeneans (Platyhelminthes) with insights into biogeographic variability. Parasitol. Int. 59: $183-91$.

\section{Explanation of Figures}

Photomicrographs of Serrasentis sagittifer infecting Pagrus pagrus fish:

Fig. 1- Adult worm as a whole mount preparation with a protrusible proboscis $(\mathrm{P})$, followed by a proboscis receptacle (PE), male with two testis (TE) and a primordial of cementglands (CG) at body posterior end.

Fig. 2: adult worm anterior end with an inverted proboscis $(\mathrm{P})$.

High magnifications of:

Figs. 3 \&4: Proboscis (P) with a multiple rows of spines (SP).

Fig. 5: Combs of body spines.

Fig. 6: Posterior end of female.

Fig. 7: Posterior end of male with cement glangs (CG).

Fig. 8: Two testes (TE).

Scanning electron micrographs of Serrasentis sagittifer:

Fig. 9: Proboscis (P) with spines (SP). Fig. 10 Combs of body spines (SP).

Figs. $11 \& 12$ : High magnifications of Proboscis spines (SP), and Trunk spines (SP). 


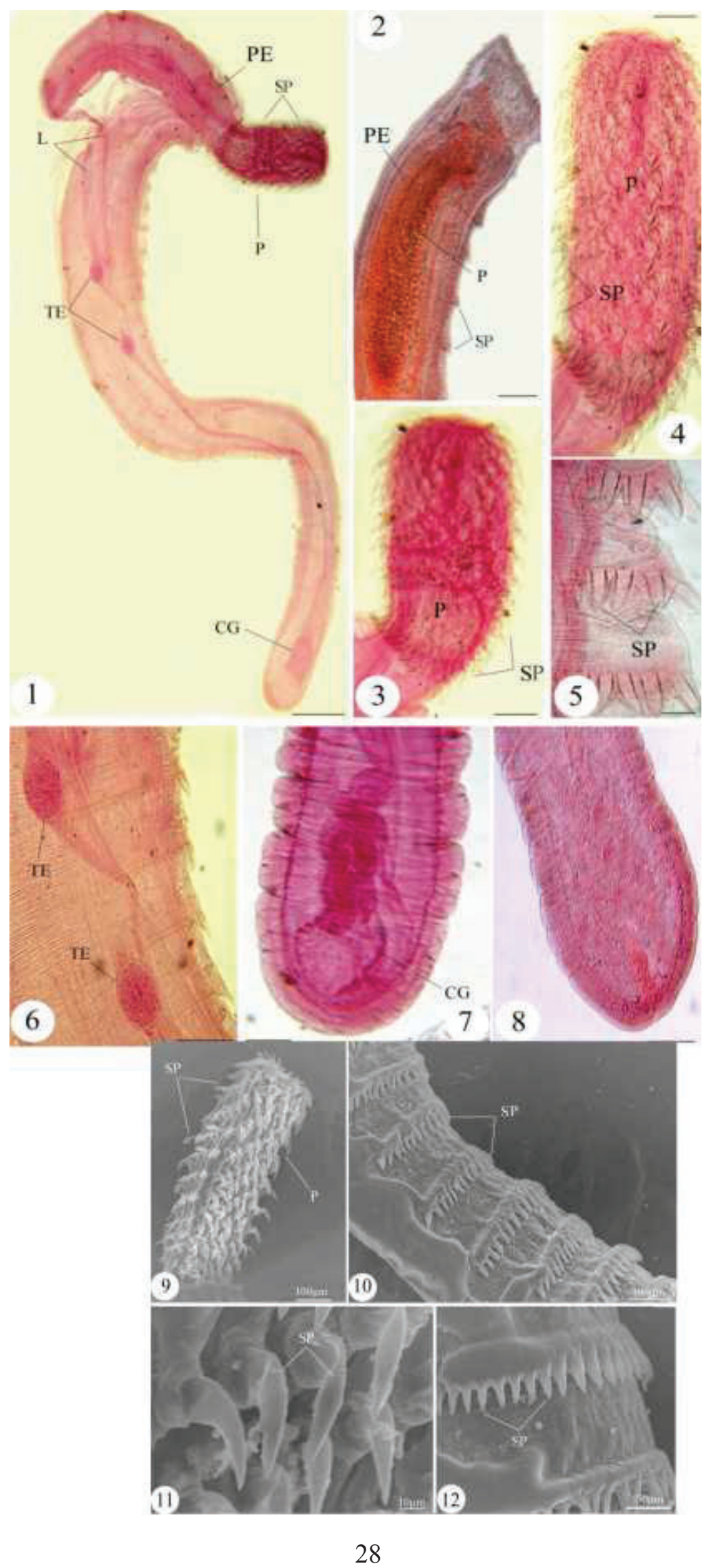

